BAREKENG: Jurnal Ilmu Matematika dan Terapan June $2021 \quad$ Vol. 15 No. $2 \quad$ Page 297-304

P-ISSN: 1978-7227 E-ISSN: 2615-3017

\title{
OPTIMIZATION OF LAMPUNG BATIK PRODUCTION USING THE SIMPLEX METHOD
}

\author{
Ahmad Ari Aldino ${ }^{1 *}$, Marchamah Ulfa ${ }^{2}$ \\ ${ }^{1}$ Department of Informatics, Faculty of Engineering and Computer Science, Universitas Teknokrat Indonesia \\ ${ }^{2}$ Department of Mathematics Education, Faculty of Literature and Education, Universitas Teknokrat Indonesia \\ Jl. Z. A. Pagar Alam No. 9 -11, Labuhan Ratu, Kedaton, Bandar Lampung, Lampung, 35132, Indonesia
}

Corresponding author e-mail: $1 *$ aldino@teknokrat.ac.id

\begin{abstract}
Abstrak
The Production and Profit optimization application in this Batik company was built to solve their problems. This application has the ability to process raw material data, working time data, production requirements data and load data for optimization calculations. The basis for calculations carried out includes optimization calculations using the Simplex Method and the tools used are Excel Solver and Python Programming. The output of this application is that how many Batik are produced based on available resources, the total cost of expenses incurred during the production process as well as gross profit and net of sales. This application can increase company profits and the percentage level of profit depending on the price comparison of sales between one product to another.
\end{abstract}

Keywords: Linear Programming, Simplex Method, Optimization, Python, Excel Solver 


\section{INTRODUCTION}

Nowadays, there are many micro, small and medium enterprises (MSMEs) engaged in industry, both medium and small. Business competition is getting tougher and more challenging. This condition can be seen from the increasing number of MSMEs. To be able to compete in business, MSMEs must have a strategic place and the availability of products to fulfill market demand. This has resulted in many MSMEs competing with each other to be in the forefront and have quality products in their sector [1][2][3]. The production process has a very crucial role. Because production activities determine the course of business and the amount of company income [4][5]. To be able to compete in the global market, MSMEs need good production planning and management. With good management, MSMEs can increase profits from limited available resources [6][7].

Lampung batik was first introduced by Andrean Sangaji (a Lampung cultural observer) in 1970. This batik has its own distinctive features, some of the popular styles are the living tree pattern and the boat pattern. Batik Lampung is indeed less popular than Batik Jogja and Solo, however, there are many enthusiasts of this type of batik. It is proven by the number of Batik production houses in Lampung Province. One of the famous ones is Andanan Batik Lampung, which is located at Negeri Sakti Persada Housing, Negeri Sakti Village, Negeri Katon District, Pesawaran Regency, Lampung Province.

Andanan Batik Lampung always has a different sales volume every time because of uncertain market demand. Even these MSMEs have not used a planning system in regulating the amount of production so that there are still a lot of products in stock. Therefore, to get the optimal solution of this problem, it is necessary to hold a planning optimization of the amount of production for each product so that these MSMEs can reap more profits [8][9]. Based on the observations of researchers, it was found that there was a difference between the number of products sold and the number of production goods, this was a nonoptimal condition for MSMEs because production did not match sales, resulting in over production [10].

Problems related to the process of maximizing profit or minimizing production costs are called optimization [11]. Because the factors of production, products made, and the amount of profit are linearly correlated, so it is necessary to solve optimization problems [12][4]. In this case, the linear analysis tool used is the Simplex method. Simplex is a method used for solving linear program problems involving many variables and many inequalities by doing iteration / repeated calculations until the optimal solution is obtained [12][13]. Solving linear program problems requires determining the constraints faced, then converted into a Mathematical model. Creating a mathematical model on linear programming problems is to determine the objective function and the constraints / conditions that must be met [14][15]. Based on these problems, the researcher chose the title "Optimization of Lampung Batik Production Using the Simplex Method (Case Study: Andana Batik Lampung)" as the research.

\section{RESEARCH METHOD}

In order for the purpose of the research to be achieved, there are steps that must be taken [16][10]. The steps are:

a. Identification of problems

The problem faced by Andanan Batik Lampung is maximizing profits with limited capital, raw materials, time, and labor.

b. Model selection

The model used in problem solving is a linear program maximization problem model with the simplex method.

\section{c. Data collection}

The data were collected by means of literature study, observation, and interviews with Andanan Batik Lampung. The data needed in this research are raw materials for production, labor, production time, production, amount of production, and profit per dozen.

\section{d. Data processing and analysis}

Data processing and analysis using the simplex method with analysis tools using Python Programming and Excel Solver. 


\section{e. Model implementation}

Model implementation is done by identifying decision variables, objective functions and constraint functions.

\section{f. Results Evaluation}

The evaluation of the results is carried out by analyzing the value generated by Python Programming and Excel Solver in the previous step. The evaluation of the results was also carried out by comparing the results of the study with the actual conditions in Andanan Batik Lampung.

\section{RESULTS AND DISCUSSION}

In the application of a mathematical model to determine the number of Batik production begins by setting the target first, where the objective function is something the company wants to achieve. Then the constraint function is an obstacle that becomes a barrier to production activities [17]. In the discussion of this problem, several assumptions are used, namely:

1. Availability of raw materials, time and machines.

2. Work productivity in achieving the expected product capacity.

3. The objective function is to maximize the benefits of Batik sold.

4. The constraint function is the amount of raw materials, time and available machines.

5. The decision variables used are:

$$
\begin{aligned}
& X_{1}=\text { Printed Batik } \\
& X_{2}=\text { Handmade Batik } \\
& X_{3}=\text { Batik Scarf }
\end{aligned}
$$

\subsection{Objective Function}

The objective function to be achieved is to maximize profits, total profit through the use of available sources in the company optimally. Limited production factors encourage company to try to determine the policies that must be taken. This situation can be overcome by determining the right amount of production. Production cost and profit can be seen in Table 1 and Table 2 respectively.

Table 1. Production Cost

\begin{tabular}{cccc}
\hline Variable & $\begin{array}{c}\text { Printed Batik (IDR)/ } \\
\text { dozen }\end{array}$ & $\begin{array}{c}\text { Handmade Batik (IDR)/ } \\
\text { dozen }\end{array}$ & $\begin{array}{c}\text { Batik Scarf (IDR)/ } \\
\text { dozen }\end{array}$ \\
\hline Fabric & 420.000 & 480.000 & 180.000 \\
\hline Tailor & 100.000 & 200.000 & 50.000 \\
\hline Accessories & 10.000 & 12.000 & 3.000 \\
\hline Dye & 30.000 & 35.000 & 15.000 \\
\hline Sum & 560.000 & 727.000 & 248.000 \\
\hline Source: Production Cost Report in November 2020 at CV. Andanan Batik Lampung
\end{tabular}

Table 2. Profit

\begin{tabular}{cccc}
\hline Product & $\begin{array}{c}\text { Cost of goods sold } \\
\text { (IDR)/ dozen }\end{array}$ & $\begin{array}{c}\text { Production Cost } \\
\text { (IDR)/ dozen }\end{array}$ & Profit (IDR)/ dozen \\
\hline $\begin{array}{c}\text { Printed } \\
\text { Batik }\end{array}$ & 615.000 & 560.000 & 55.000 \\
\hline $\begin{array}{c}\text { Handmade } \\
\text { Batik }\end{array}$ & 805.000 & 727.000 & 78.000 \\
\hline Batik Scarf & 280.000 & 248.000 & 32.000 \\
\hline
\end{tabular}

Source: Production Cost Report in November 2020 at CV. Andanan Batik Lampung

The objective function is:

Maximize $Z=55.000 X_{1}+78.000 X_{2}+32.000 X_{3}$ 
Where:

$$
\begin{aligned}
& Z=\text { Maximum Profit } \\
& X_{1}=\text { Printed Batik } \\
& X_{2}=\text { Handmade Batik } \\
& X_{3}=\text { Batik Scarf }
\end{aligned}
$$

\subsection{Constraint Function}

The constraints faced by the company are capacity, time and available machines. The price of each type of product is:

Table 3. Total Requirements

\begin{tabular}{cccc}
\hline Product & Raw Materials/ Kg & Time/ Second & Machine/ Unit \\
\hline Printed Batik & 0,315 & 400 & 16 \\
\hline Handmade Batik & 0,350 & 650 & 20 \\
\hline Batik Scarf & 0,150 & 1.000 & 10 \\
\hline Source: Production Cost Report in November 2020 at CV. Andanan Batik Lampung
\end{tabular}

The number of needs that must be produced from each type of clothing as the following:

1. Printed Batik $=450$ dozen

2. Handmade Batik $=375$ dozen

3. Batik Scarf $=295$ dozen

\section{Constraint Function I}

The available fabric capacity is $1.500 \mathrm{~kg}$ for 3 types of clothes, namely:

1. Printed Batik

$$
\begin{array}{ll}
\text { Available fabric } & =0,315 \mathrm{~kg} \\
\text { Result } & =0,328 \times 450 \\
& =141,75 \mathrm{~kg} / \text { dozen } \\
\text { 2. Handmade Batik } & \\
\begin{array}{l}
\text { Available fabric } \\
\text { Result }
\end{array} & =0,350 \mathrm{~kg} \\
& =0,350 \times 375
\end{array}
$$

3. Batik Scarf

Available fabric $\quad=0,295 \mathrm{~kg}$

Result $\quad=0,295 \times 295$

Constraint Function I:

$$
=87,025 \mathrm{Kg} / \text { dozen }
$$

$$
=141,75 X_{1}+131,25 X_{2}+87,025 X_{3}
$$

\section{Constraint Function II}

The time needed in the process of making the 3 types of Batik is counted in hours. We take 1 day as 24 hours. The maximum time to complete the 3 types of clothes is :

time (hours) $\mathrm{x}$ how many types of Batik x maximum time for work

$24 \times 3 \times 7.5=540$ hours

1. Printed Batik

Processing time $=650$ seconds

Result

$$
\begin{aligned}
& =3600 / 650 \\
& =5,5 \text { hours } x 7,5 \text { hours }
\end{aligned}
$$$$
=41,5 \text { hours }
$$

2. Handmade Batik

Processing time

Result

$=400$ seconds

$=3600 / 400$

$=9$ hours $\times 7,5$ hours

$=67,5$ hours

3. Batik Scarf

Processing time

$=1.000$ seconds 
Result

$$
\begin{aligned}
& =3600 / 1.000 \\
& =3,6 \text { hours } \times 7,5 \text { hours }
\end{aligned}
$$

$=27$ hours

Constraint Function II:

$=41,5 X_{1}+67,5 X_{2}+27 X_{3}$

\section{Constraint function III}

In the machines capacity on these 3 types of Batik, only 175 machines are available

1. Printed Batik

Available machines $=16$ Units

2. Handmade Batik

Available machines $=20$ units

3. Batik Scarf

Available machines $=10$ units

Constraint Function III:

$=16 X_{1}+20 X_{2}+10 X_{3}$

\subsection{The Simplex Method}

After obtaining each objective function and constraint function with calculations from the available data, then the application OF simplex method model is written as follows:

Objective Function: $Z=55.000 X_{1}+78.000 X_{2}+32.000 X_{3}$

Constraint Function:

$141,75 X_{1}+131,25 X_{2}+87,025 X_{3} \leq 1.500$

$41,5 X_{1}+67,5 X_{2}+27 X_{3} \leq 540$

$16 X_{1}+20 X_{2}+10 X_{3} \leq 175$

Where: $X_{1}, X_{2}, X_{3} \geq 0$

After that, it is converted into the same model by adding the slack variable to each variable and giving a value of 0 to each coefficient $S$, so that the form of the objective function equation in the simplex method becomes:

$Z=55.000 X_{1}+78.000 X_{2}+32.000 X_{3}+0 S_{1}+0 S_{2}+0 S_{3}$

The slack variable of the constraint functions are:

$141,75 X_{1}+131,25 X_{2}+87,025 X_{3}+S_{1}=1.500$

$41,5 X_{1}+67,5 X_{2}+27 X_{3}+S_{2}=540$

$16 X_{1}+20 X_{2}+10 X_{3}+S_{3}=175$

The next step is that after obtaining the standard form of the simplex method equation, the problem of solving the amount of production that involves more than two variables can be solved using the simplex method with the help of Excel Solver and Python Programming. Then apply the simplex standard form into a simplex table which is done iteratively in a certain amount so as to get the optimal results. The application of the simplex table is as follows:

Table 4. Simplex Table Iteration 1

\begin{tabular}{cccccccccc}
\hline \multirow{2}{*}{ Coefficient } & CJ & $\mathbf{5 5 0 0 0}$ & $\mathbf{7 8 0 0 0}$ & $\mathbf{3 2 0 0 0}$ & & & & Value & Ratio \\
\cline { 2 - 11 } & Variable & $\mathbf{X 1}$ & $\mathbf{X 2}$ & $\mathbf{X 3}$ & $\mathbf{S 1}$ & $\mathbf{S 2}$ & $\mathbf{S 3}$ & & \\
\hline 0 & $\mathbf{S 1}$ & 141,75 & 131,25 & 87,025 & 1 & 0 & 0 & 1500 & 11,42857 \\
\hline 0 & $\mathbf{S 2}$ & 41,5 & 67,5 & 27 & 0 & 1 & 0 & 540 & 8 \\
\hline 0 & $\mathbf{S 3}$ & 16 & 20 & 10 & 0 & 0 & 1 & 175 & 8,75 \\
\hline & TRJ & 0 & 0 & 0 & 0 & 0 & 0 & 0 & \\
\cline { 2 - 11 } & CJ - TRJ & 55000 & 78000 & 32000 & & & & & \\
\hline
\end{tabular}


Table 5. Simplex Table Iteration 2

\begin{tabular}{cccccccccc}
\hline \multirow{2}{*}{ Coefficient } & CJ & $\mathbf{5 5 0 0 0}$ & $\mathbf{7 8 0 0 0}$ & $\mathbf{3 2 0 0 0}$ & & & & Value & Ratio \\
\cline { 2 - 10 } & Variable & $\mathbf{X 1}$ & $\mathbf{X 2}$ & $\mathbf{X 3}$ & $\mathbf{S 1}$ & $\mathbf{S 2}$ & $\mathbf{S 3}$ & & \\
\hline 0 & $\mathbf{S 1}$ & 61,0556 & 0 & 34,525 & 1 & $-1,94$ & 0 & 450 & 7,370337 \\
\hline 78000 & $\mathbf{S 2}$ & 0,61481 & 1 & 0,4 & 0 & 0,015 & 0 & 8 & 13,01205 \\
\hline 0 & $\mathbf{S 3}$ & 3,7037 & 0 & 2 & 0 & $-0,3$ & 1 & 15 & 4,05 \\
\hline & $\mathbf{T R J}$ & 47955,6 & 78000 & 31200 & 0 & 1156 & 0 & 624000 & \\
\cline { 2 - 10 } & CJ - TRJ & 7044,44 & 0 & 800 & 0 & -1156 & 0 & & \\
\hline
\end{tabular}

Table 6. Simplex Table Iteration 3

\begin{tabular}{ccccccccc}
\hline \multirow{2}{*}{ Coefficient } & CJ & $\mathbf{5 5 0 0 0}$ & $\mathbf{7 8 0 0 0}$ & $\mathbf{3 2 0 0 0}$ & & & \multicolumn{2}{c}{ Value } \\
\cline { 2 - 10 } & Variable & $\mathbf{X 1}$ & $\mathbf{X 2}$ & $\mathbf{X 3}$ & $\mathbf{S 1}$ & $\mathbf{S 2}$ & $\mathbf{S 3}$ & \\
\hline 32000 & $\mathbf{S 1}$ & 0 & 0 & 1,555 & 1 & 2,94 & $-16,485$ & 4,05 \\
\hline 78000 & $\mathbf{S 2}$ & 0 & 1 & 0,068 & 0 & 0,064 & $-0,166$ & 5,51 \\
\hline 55000 & $\mathbf{S 3}$ & 1 & 0 & 0,54 & 0 & $-0,08$ & 0,27 & 0 \\
\hline & TRJ & 72280 & 80176 & 121860 & 32000 & 94672 & -525618 & 652530 \\
\cline { 2 - 9 } & CJ - TRJ & -17280 & -2176 & -89860 & -32000 & -94672 & 525618 & \\
\hline
\end{tabular}

A result was obtained that the solution was optimal, because there were no more non-basic variables that had a value greater or equal than 1 . Where the optimal production of each type of Batik is:

$X_{1}$ : Printed Batik = 4,05 dozen

$X_{2}$ : Handmade Batik = 5,51 dozen

$X_{3}:$ Batik Scarf $=0$ dozen

\subsection{Simplex Method Using Excel Solver}

The following Table 7 shows the simplex method using Excel Solver Function in Microsoft Excel 2019.

Table 7. Simplex Method Using Excel Solver

\begin{tabular}{ccccccc}
\hline Decision Variables & $\mathbf{X 1}$ & $\mathbf{X 2}$ & $\mathbf{X 3}$ & $\begin{array}{c}\text { Objective } \\
\text { Value }\end{array}$ & & \\
\hline Value & 4,05 & 5,51 & 0 & 652530 & & \\
\hline Coefficients & 55000 & 78000 & 32000 & & RHS \\
\hline Constraint 1 & 141,75 & 131,25 & 87,025 & 1297,275 & $\leq$ & 1500 \\
\hline Constraint 2 & 41,5 & 67,5 & 27 & 540 & $\leq$ & 540 \\
\hline Constraint 3 & 16 & 20 & 10 & 175 & $\leq$ & 175 \\
\hline
\end{tabular}

The result shows that the optimal Batik produced are 4,05 dozen for Printed Batik and 5,51 dozen for Handmade Batik. The optimal profit is IDR 652.530/ dozen

\subsection{Simplex Method Using Python Programming}

The following code shows the simplex method using Python Programming.

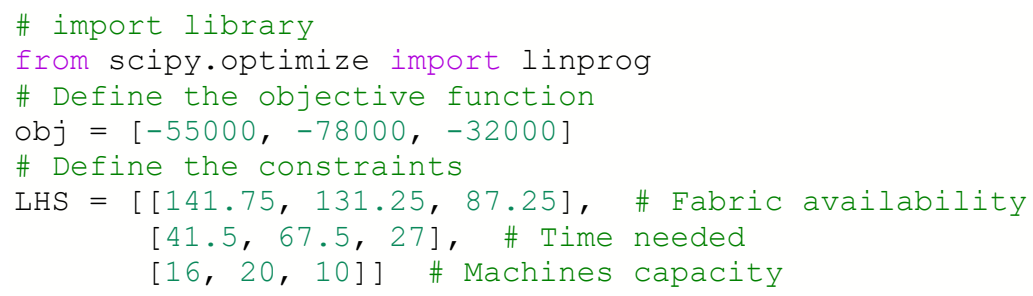




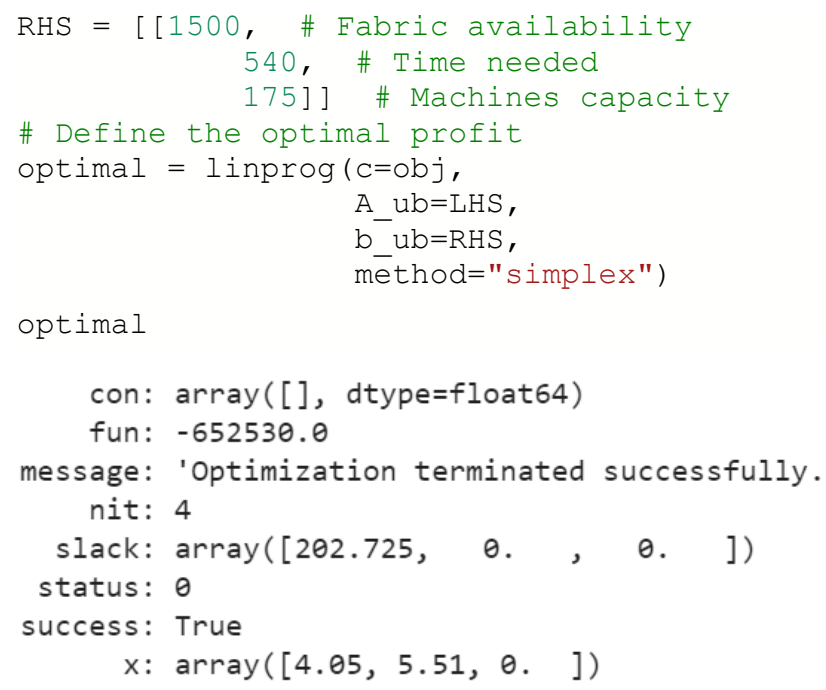

\section{CONCLUSION}

The conclusion of this research is the company must produce 4,05 dozen Printed Batik and 5,51 Handmade Batik to obtain the maximum result which is expected to be IDR 652.530. In the next production, they should try to apply simplex method at the earlier stage, such as determining constraints so that later decision making can be easier and more precise. In addition, the change from a linear programming model to a linear equation before solving using the simplex method requires accuracy so that it is not mistaken when iterated. And in the future, it will be more computerized, it will make it easier to make decisions.

\section{REFERENCES}

[1] D. Agustina, B. S. Anggoro, and D. Anggraini, "Optimasi Penjualan Laptop Asus dan Acer dengan Metode Simpleks," J. UJMC, vol. 4, no. 1, pp. 1-8, 2017.

[2] N. Vaidya and N. Kasturiwale, "Application of Quick Simplex Method (A New Approach) On Two Phase Method," Br. $J$. Math. Comput. Sci., vol. 16, no. 1, pp. 1-15, 2016, doi: 10.9734/bjmcs/2016/24440.

[3] B. S. Anggoro, R. M. Rosida, A. M. Mentari, C. D. Novitasari, and I. Yulista, "Profit Optimization Using Simplex Methods on Home Industry Bintang Bakery in Sukarame Bandar Lampung," J. Phys. Conf. Ser., vol. 1155, no. 1, 2019, doi: 10.1088/1742-6596/1155/1/012010.

[4] M. A. Treiber, "Linear Programming and the Simplex Method," Optim. Comput. Vis., pp. 67-85, 2013, doi: 10.1007/978-14471-5283-5_3.

[5] M. R. Aulia, D. N. Putra, S. Murniati, M. Mustahiroh, D. Octavia, and Y. Budiasih, "Maksimalisasi Keuntungan Dengan Pendekatan Metode Simpleks Studi Kasus pada Pabrik Sendai X di Ciputat, Tangerang Selatan,” Liquidity, vol. 2, no. 2, pp. 144-150, 2018, doi: 10.32546/lq.v2i2.116.

[6] E. T. Susdarwono, "Pemrograman Linier Permasalahan Ekonomi Pertahanan: Metode Grafik Dan Metode Simpleks," Teorema Teor. dan Ris. Mat., vol. 5, no. 1, p. 89, 2020, doi: 10.25157/teorema.v5i1.3246.

[7] Suryanto, E. S. Nugroho, and R. A. K. Putra, "Analisis Optimasi Keuntungan dalam Produksi Keripik Daun Singkong dengan Linier Programming melalui Metode Simpleks,” J. Manaj., vol. 11, no. 2, pp. 226-236, 2019.

[8] M. R. Hussain, M. Qayyum, and M. E. Hussain, "Effect of seven steps approach on simplex method to optimize the mathematical manipulation," Int. J. Recent Technol. Eng., vol. 7, no. 5, pp. 34-43, 2019.

[9] A. K. Jain, R. Bhardwaj, H. Saxena, A. Choubey, and S. Ahmed, "An Approach to Maximize Profit of a Constructing Project within Limited Budget by Using Simplex Method," Int. J. Eng. Adv. Technol., vol. 6, no. 6, pp. 786-791, 2015.

[10] A. K. Jain, H. Saxena, R. Bhardwaj, G. V. V. Jagannadha Rao, and C. Siddharth Nanda, "Application of linear programming for profit maximization of a Pharma Company," J. Crit. Rev., vol. 7, no. 12, pp. 1118-1123, 2020, doi: 10.31838/jcr.07.12.195.

[11] A. Saryoko, "Metode Simpleks dalam Optimasi Hasil Produksi,” J. Informatics Educ. Prof., vol. 1, no. 1, pp. $27-36,2016$.

[12] S. Narayanamoorthy and S. Kalyani, "The intelligence of dual simplex method to solve linear fractional fuzzy transportation problem," Comput. Intell. Neurosci., vol. 2015, 2015, doi: 10.1155/2015/103618.

[13] S. I. Purnama, I. Hikmah, M. A. Afandi, and E. S. Mulyani, "MENGGUNAKAN REGRESI LINIER Thermal Camera Temperature Readings Optimization Using Linear Regression,” Barakeng J. Ilmu Mat. dan Terap., vol. 15, no. 1, pp. 127136, 2021.

[14] A. Metode, K. Untuk, and M. Masalah, "Analisis Metode Karmarkar Untuk Menyelesaikan Masalah Program Linier," J. MIPA, vol. 36, no. 1, pp. 1-1, 2014.

[15] R. L. Rumahorbo and A. Mansyur, "Konsistensi metode simpleks dalam menentukan nilai optimum," Karismatika, vol. 3, no. 
1, pp. 36-46, 2017.

[16] E. Jain and K. Dahiya, "A Note on Dual Simplex Algorithm for Linear Programming Problem with Bounded Variables," vol. 20, no. 1, pp. 135-153, 2018.

[17] R. Larson, "9.3 the Simplex Method: Maximization," Elem. Linear Algebr., pp. 494-509, 2013. 